\title{
A database of Triassic conodonts from a comprehensive revision of literature
}

\section{Pablo PLASENCIA ${ }^{1,2^{*}}$, Ana MÁRQUEZ-ALIAGA² \& Jingeng SHA ${ }^{1}$}

\author{
${ }^{1}$ State Key Laboratory of Palaeobiology and Stratigraphy, Nanjing Institute of Geology and Paleontology (CAS), Nanjing, 39 \\ East Beijing Road, Nanjing, 210008, People’s Republic of China; pplasencia@nigpas.ac.cn; jgsha@nigpas.ac.cn \\ ${ }^{2}$ Departamento de Geología, Universitat de Valencia, Dr. Moliner, 50, 46100 Burjassot, Valencia, Spain; Ana.Marquez@uv.es \\ * Corresponding author
}

Plasencia, P., Márquez-Aliaga, A. \& Sha, J. 2013. A data base of Triassic conodonts from a comprehensive revision of literature. [Una base de datos de conodontos triásicos a partir de una completa revisión de la literatura]. Spanish Journal of Palaeontology,

28 (2), 215-226.

\begin{abstract}
The revision of a comprehensive amount of bibliography has made possible the development of a database containing the stratigraphic ranges of the conodont species from the uppermost Permian and the Triassic, with a total of 336 species in 52 genera. This database is aimed at biostratigraphy and studies related to biological, evolutional and palaeodiversity dynamics.
\end{abstract}

Keywords: Conodonts, stratigraphic ranges, database, Triassic.

\section{RESUMEN}

La revisión de una amplia cantidad de bibliografía ha hecho posible el desarrollo de una base de datos en la que figuran los rangos estratigráficos de las especies de conodontos presentes desde el Pérmico superior y el Triásico, con un total de 336 especies y 52 géneros. Esta base de datos está dirigida a la bioestratigrafía y a estudios relacionados con las dinámicas biológicas, evolutivas y de paleodiversidad.

Palabras clave: Conodontos, rangos estratigráficos, base de datos, Triásico. 


\section{INTRODUCTION}

Conodonts are an extinct animal group, which originated in the Middle Cambrian and lasted until the base of the Jurassic (e.g., Kozur, 1993; Pàlfy et al., 2007). Over more than 300 million years, conodonts showed a continuous evolution and rapid diversification that, combined with a high abundance and widespread geographical distribution, make them a very valuable tool in the study of many palaeontological aspects, such as biostratigraphy and palaeobiogeography. After experiencing diversity peaks during the Ordovician and Devonian periods, conodonts began a progressive long-term decline during the Carboniferous, reaching a biodiversity minimum during the Upper Permian.

The Triassic, as the first period of the Mesozoic, is a significant stage in the evolution of life, starting and ending with a great biotic crisis, both of which belonged to the socalled "Big Five" extinction events, marking the decadence of the Palaeozoic evolutionary fauna and the expansion of the modern evolutionary faunas (Sepkoski, 1981).

The first event was the Permian-Triassic (PTB) boundary, regarded as the most severe crisis in the history of life (e.g., Hallam \& Wignall, 1997; Benton \& Twitchett, 2003), which represented a global turnover in the biosphere, especially in marine ecosystems (Erwin, 2006). The ecological recovery from this extinction is regarded to have been slower than after other extinction events, in many cases lasting until the Middle Triassic (Benton \& Twitchett, 2003; Lehrmann et al., 2006). However, this is not the case for conodonts, which experienced a quick recovery during the earliest part of the Triassic (Plasencia \& Márquez-Aliaga, 2005; Stanley, 2009; Fröbisch et al., 2012), followed by several crises and recoveries in the course of the Middle and Upper Triassic.

Most of the genera of three families (Anchignathodontidae, Ellisonidae and Gondolellidae) survived, crossing the Permian-Triassic boundary into the Triassic. However, there were significant changes at the specific level, the main one being the diversification of the Anchignathodontidae family during the latest Permian, compensating for the reduction of representatives of the Gondolellidae.

The second event was the Triassic-Jurassic boundary (TJB), which sealed the disappearance of conodonts that had gradually been starting during the latest part of the Triassic. While the TJB extinction is regarded as less important than that at the end of the Permian, at least in the context of ecosystem changes, it nevertheless represents a large taxonomic turnover (more than $50 \%$ of species lost; Sepkoski, 1996).

As a result of research over several generations, a comprehensive amount of information has been accumulated on many different aspects of conodonts.

We have compiled the stratigraphic ranges and worldwide geographic distribution of Triassic conodont species, as comprehensively as possible and adapted to the modern taxonomy, in which the species present in the uppermost Wuchiapingian and the Changhsingian of the Lopingian (Late Permian) are included, in order to evaluate the effects that the mass extinction of the PTB could have had on the group.

In the present paper we present part of this database, which consists of a list of accepted species with their stratigraphic ranges. This data will be the base for future works in order to study the evolutionary dynamics of conodonts across the PTB and the Triassic. It can be used as a reference for other studies, beyond the study of conodonts, for a much wider audience interested in the study of biological, evolutional and palaeodiversity dynamics.

Biodynamical analysis papers related to Triassic conodonts are scarce, apart from the above-cited works by Clark (1987) and De Renzi et al. (1996), diverse aspects of the groups have also been studied by Clark (1983) and Plasencia \& Márquez-Aliaga (2005). Recently, Stanley (2009) developed an analysis of the Early Triassic conodonts using data from Orchard (2007a), but this paper was not originally developed for this purpose and lacks some important data, mainly the ranges of the members of the Anchignathodontidae family, which is the most important in the earliest part of the Triassic. There has also been a significant number of new species described since Orchard's paper was published in 2007.

\section{MATERIALS AND METHODS}

In comparison with other groups, research into Triassic conodonts is relatively recent; Eicher (1946) reported for the first time the presence of conodonts in strata of unequivocally Triassic age in Sinai (Egypt). This was received with some scepticism [see the discussion by Branson \& Mehl (1946) at the end of the same paper], and it was not until the 1950s that the existence of Triassic conodonts was finally fully recognized and accepted, with pioneer works such as those by Youngquist (1952), Müller (1956) and Tatge (1956) marking the beginning of a continuous research work that has lasted until the present day.

\subsection{Development of the database}

For the purposes of the present study, a revision of the available bibliography from the early 1950s until 2012 was undertaken, in order to identify as many different candidate taxa as possible. The resulting list of species was studied to include or exclude species as "valid". We tried to reduce subjective aspects as much as possible by setting several criteria that a species should meet in order 
to be considered valid but, ultimately, any selection will have some subjectivity and is open to discussion. So, all the accepted species needed to meet the following requirements:

1) An adequate taxonomic diagnosis and description. When needed, a translation from the original language was undertaken. An adequate illustration of at least the holotype was considered desirable but not essential when better pictures of other specimens, clearly identifiable as being of the same species, are available. This requirement obliged us to exclude species in open nomenclature. A few exceptions were made (Vjalovognathus n. sp. B, Merrillina sp.) in order to make explicit the presence of both genera in the Wuchiapingian and lower Changhsingian.

2) Support from a list of different papers with a coherent characterization of the species, following the original description. As a general rule, at least three different references were required. However, exceptions were made, especially for species recently described but not yet considered in other works, or having morphologies that present clear diagnostic characteristics but with a limited distribution.

3) A well-defined stratigraphic range.

4) We did not take into consideration subspecies or morphotypes as independent taxa; the stratigraphic range of these taxonomic levels was grouped together in order to summarize the complete stratigraphic range of the species.

Two lists were established: one for the species that adequately met all the established criteria (Accepted Species) and a second for those species that were rejected.

\subsection{Selected bibliography}

Several hundreds of papers were compiled during the development of the database. Not all of these contained useful information about the stratigraphic ranges of the species, and most were basically redundant. Since a complete list of this bibliography would be impractical, we selected one to three papers for each species that justified the stratigraphic range that we have accepted.

The papers selected for the Upper Permian species were: Algeo et al. (2012), Beyers \& Orchard (1991), Gullo \& Kozur (1992), Henderson (1997), Jiang et al. (2011a,b), Korte \& Kozur (2010), Kozur (1990, 1995a, b, 2004, 2005, 2007), Kozur \& Weems (2011), Mei et al. (1994, 1998), Nafi et al. (2006), Orchard (2007a, 2010), Orchard \& Krystyn (1998), Orchard et al. (2001a), Perri (1991), Perri \& Angraghetti (1987), Perri \& Farabegoli (2003), Shen (2007), Shen \& Mei (2010), Sweet \& Mei (1999) and Wang et al. (1987).

For the Lower Triassic species: Balini et al. (2000), Baud et al. (2011), Goudemand et al. (2012), Hirsch (1994), Ji et al. (2010), Jiang et al. (2007, 2011b), Koike
(1998), Koike et al. (1985), Kozur (1996), Kozur et al. (1997), Krystyn et al. (2007), Liang et al. (2011), Meço (1999), Metcalfe et al. (2008), Orchard (1995, 2007b, 2008, 2010), Orchard \& Zonneveld (2009), Orchard et al. (2007a), Perri \& Farabegoli (2003), Posenato (2008), Trammer (1975), Zhao (2004), Zhao et al. (2007, 2008).

For the Middle Triassic species: Balini et al. (2000), Benjamini et al. (2005), Brack \& Nicora (1998), Brack et al. (2005), Budurov \& Stefanov (1973), Budurov \& Sudar (1988), Buser et al. (2007), Chen \& Wang (2002), Gullo \& Kozur (1989), Hirsch (1994), Hornung et al. (2007), Ishida et al. (2006), Koike (1999), Kovács (1994), Kovács \& Kozur (1980), Kozur (2003), Kozur et al. (1994), MárquezAliaga et al. (2000), Mastandrea et al. (1997), Mietto \& Petroni (1980), Mietto et al. (2007), Muttoni et al. (2000, 2004), Nakazawa et al. (1994), Nakrem et al. (2008), Narkiewicz (1999), Narkiewicz \& Szulc (2004), Orchard (2010), Orchard \& Tozer (1997), Plasencia \& MárquezAliaga (2011), Plasencia et al. (2007), Rigo et al. (2007), Sun et al. (2006) and Vrielynck (1984).

For the Upper Triassic species: Belvedere et al. (2008), Budurov \& Sudar (1990), Buryi (1996), Buser et al. (2007), Carter \& Orchard (2007), Channell et al. (2003), Hirsch (1994), Ishida \& Hirsch (2001), Ishida et al. (2006), Kolar-Jurkovsek (1982, 2011), Kozur (2003), Kozur \& Mock (1991), Krystyn (1983, 2008), Krystyn et al. (2007, 2009), Mazza et al. (2010, 2011, 2012), Moix et al. (2007), Mosher (1973), Muttoni et al. (2000, 2010), Nicora et al. (2007), Noyan \& Kozur (2007), Orchard (1991, 2010), Orchard et al. (2001b, 2007b), Rigo et al. (2007), Rozic et al. (2009), Swift (1989) and Yang (1995).

\section{RESULTS}

A total of 336 species and 52 genera were considered. This number was significantly higher than other similar databases used in previous works: about 100 species in 19 genera in Clark (1987), and 107 species and 26 genera in De Renzi et al. (1996). Part of this difference was due to the number of species that have been described since these two papers were published (25 and 16 years, with 131 and 73 new species described, respectively); our database also comprises a number of species only present in the Permian (33) that were probably not taken in count by the authors.

The complete data has been summarized in the supplementary information as an Excel spreadsheet.

In this file the stratigraphic ranges of the accepted species are given, including the observed first and last appearances of each one. In order to facilitate the review of the data and justify the assigned age, one or two papers (in some rare cases, up to three) were selected for each species from which the range information can be checked. Where possible, the most modern and complete papers were 
selected; the list can be found pointing section 2.2. This information is set out in the Excel sheet named "Species". The sheet "RAW" contains a binary representation of the data: 1 for presence and 0 for absence of a species within a unit of time.

Chronostratigraphic scale: we used the ICS (International Commission on Stratigraphy) scale in which the Lopingian (Upper Permian) is subdivided into two stages, while the Triassic comprises three series and seven stages (Fig. 1). While not formally accepted by the ICS, the 15 substage divisions of the Triassic (Tab. 1) have been widely used by specialists for many years and represent a standard for the period.

Time units: a further subdivision of each substage in the Early, Middle and Late units is in use, with the exception of the Sevatian, which has only two subdivisions (Early and Late); for each of the Changhsingian and Rhaetian the three units were made equivalent to substages, and only the upper part of the Wuchiapingian was considered in our study. In total, there were 51 divisions, named "time units" (Tab. 1).

Each of these units was made equivalent to an ammonoid or conodont biozone, as shown in the Table 1, in order to simplify the data selection: if a conodont species was recognized in one of these biozones (or equivalent), it was marked as "1" in the corresponding time unit in the spreadsheet, and if not, a "0" was marked. The biozones were taken from Orchard (2007a) for the Lower Triassic and Balini et al. (2010) for the Middle and Upper Triassic [with Channell et al. (2003) for the Sevatian]. When other biozones were used, they were correlated using the files "8_Lower_Triassic.pdf" (Ogg \& Ogg, 2006a) and "7_Upper_Trias.pdf" (Ogg \& Ogg, 2006b), available at https://engineering.purdue.edu/Stratigraphy/charts/ Timeslices/ and the synthetic tables found in Balini et al. (2010).

In summary, five families, 10 genera and 52 species were present in the Upper Permian, the most significant being Hindeodus Rexroad \& Furnish 1964 and Clarkina Kozur 1989 (Figs 1a-1d). Three of these families and 17 species crossed into the Lower Triassic. The entire Lower Triassic comprised a total of 132 species, with 33 genera. The most significant genera were: for the Family Anchignathodontidae, Hindeodus and Isarcicella Kozur 1975 (Figs 1a-1b), for the Family Ellisonidae Ellisonia Múller 1956 (Fig. 1c) and for the Family Gondolellidae Neogondolella Bender \& Stoppel 1965 and Neospathodus Mosher 1968 (Figs 1e-1f). At the end of the Early Triassic, only the Family Gondolellidae remained, with seven species crossing into the Middle Triassic, and with a total of 85 species for the whole series, comprising 11 genera. Apart from Neogondolella, the most significant genera are Paragondolella Mosher 1968, Gladigondolella Müller 1962 and Sephardiella March, Budurov, Hirsch \& Márquez-Aliaga (Fig 1g-1i). Of these, 18 species crossed into the Upper Triassic, with a total of 102 species in 15 genera, with the most significant being Metapolygnathus Hayashi 1968, Epigondolella Mosher 1968 and Misikella Kozur \& Mock 1974 (Figs 1j-1).

Species rejected: a total of 103 species were included in a category "not considered", found on the Excel sheet of the same name in the supplementary information. This list includes species that did not comply with the requirements explained above; the main motive they were discarded is synthesized as follows:

Incomplete diagnosis or description

Stratigraphic range not well defined

In synonymy

Subspecies

Multielement (the species have been regarded as a multielement of another species)

Outside the considered time interval (species that, despite being present in the Late Wuchiapingian, are not present in the later part of this period).

\section{CONCLUSIONS}

The database outlined in this paper is the result of a comprehensive revision of Triassic conodont literature. As a result, a database of species, including their stratigraphic ranges for the uppermost Permian and the Triassic, was compiled, incorporating a total of 329 species belonging to 52 genera.

\section{Suplementary information}

The supplementary information can be downloaded from: http://www.sepaleontologia.es/revista/volumenesanteriores. html.

\section{ACKNOWLEDGEMENTS}

We want to thank Profs Valenzuela-Ríos (University of Valencia, Spain) and Francis Hirsch (University of Naruto, Japan) and two anonymous reviewers for their valuable comments and remarks. This work has been supported by the Chinese Academy of Sciences (Grants "2010Y2ZA02" and "XDB03010000"), the Ministry of Science and Innovation (Project CGL2011-24408) and the Ministry of Foreign Affairs and Cooperation of Spain (MAEC-AECID). 


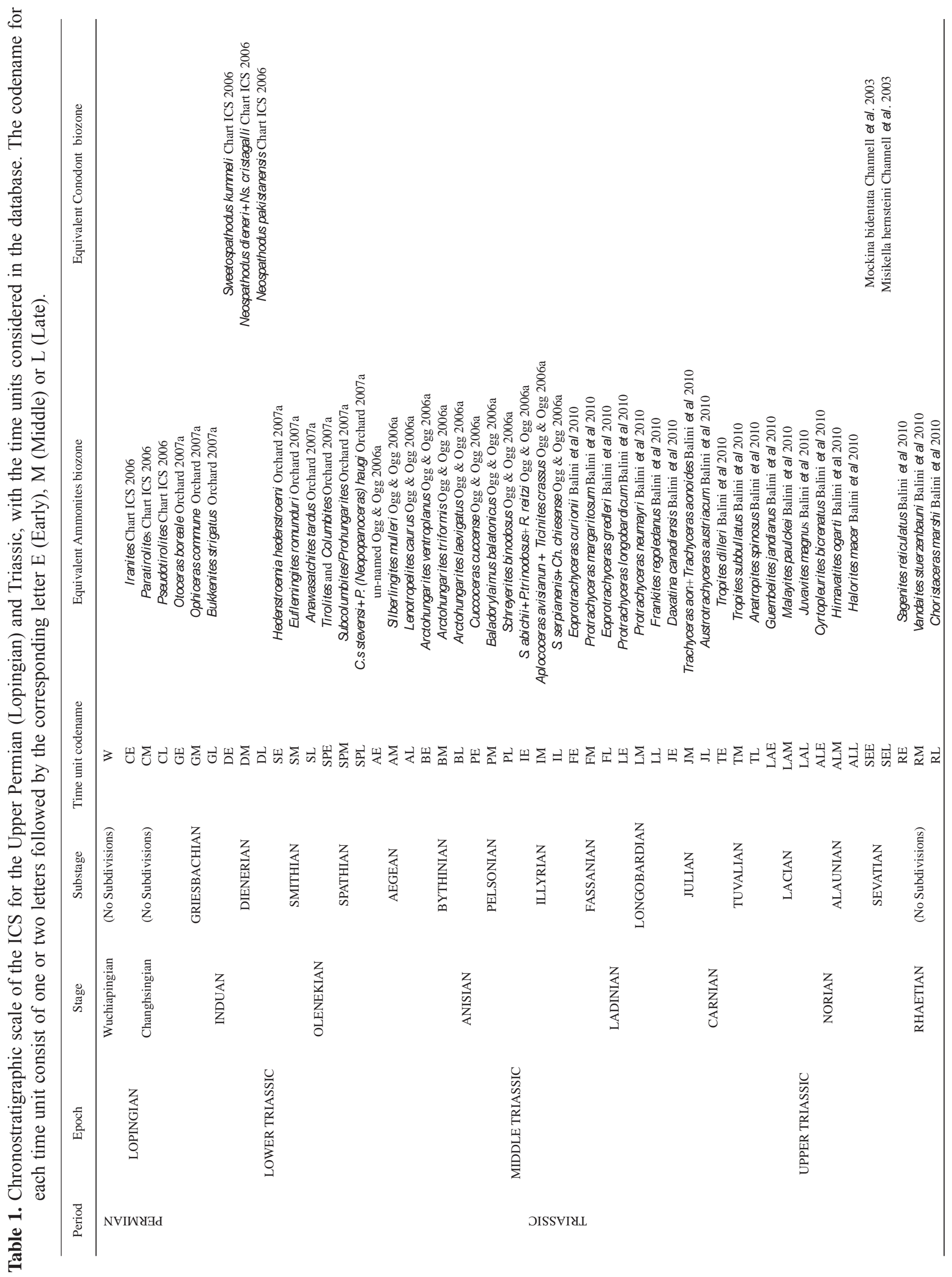



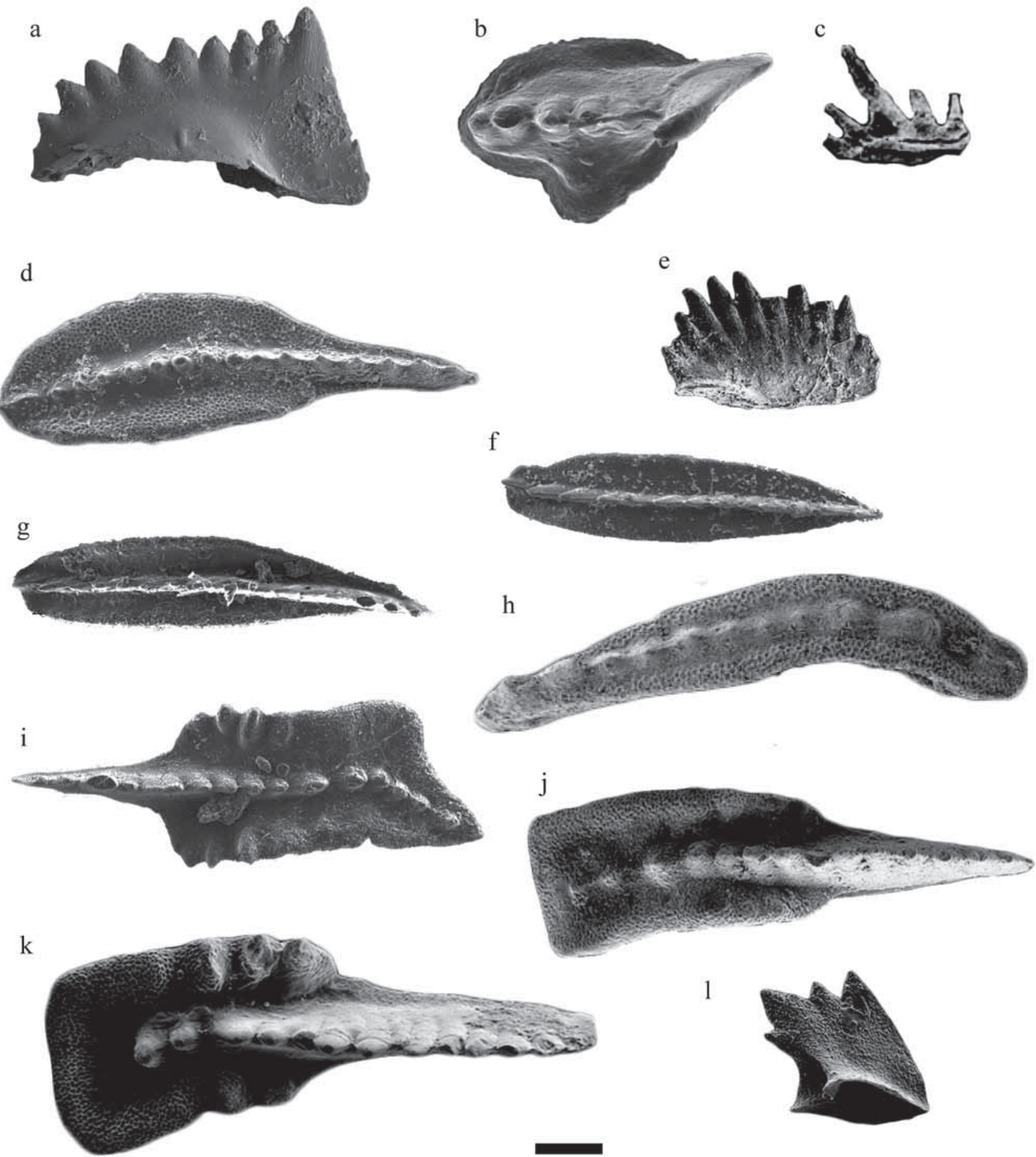

Figure 1. $P_{1}$ elements of the most significant conodont genera of the Triassic: a) Hindeodus Rexroad \& Furnish 1964 (Upper Permian-Lowermost Triassic); b) Isarcicella Kozur 1975 (Lowermost Triassic); c) Ellisonia Múller 1956 (Permian-Early Triassic); d) Clarkina Kozur 1989 (Upper Permian-Lowermost Triassic); e) Neospathodus Mosher 1968 (Lower Triassic); f) Neogondolella Bender \& Stoppel 1965 (Lower Triassic-Upper Triassic); g) Paragondolella Mosher 1968 (Middle-Upper Triassic); h) Gladigondolella Müller 1962 (Lower-Upper Triassic); i) Sephardiella March, Budurov, Hirsch \& MárquezAliaga 1990 (Middle-Upper Triassic); j) Epigondolella Mosher 1968 (Upper Triassic); k) Metapolygnathus Hayashi 1968 (Upper Triassic); l) Misikella Kozur \& Mock 1974 (Upper Triassic). Figure c comes from Koike et al. (2004), e from Liang et al. (2011), f, g, i from Plasencia (2009) and j-l from Mazza et al. (2012). Bar is $100 \mu \mathrm{m}$. 


\section{REFERENCES}

Algeo, T., Henderson, C.M., Ellwood, B., Rowe, H., Elswick, E., Bates, S., Lyons, T., Hower, J.C., Smith, C., Maynard, B., Hays, L.E., Summons, R.E., Fulton, J. \& Freeman, K.H. 2012. Evidence for a diachronous Late Permian marine crisis from the Canadian Arctic region. Geological Society of America Bulletin, in press.

Balini, M., Gavrilova, V.A. \& Nicora, A. 2000. Biostratigraphical revision of the classic Lower Dolnapa section (Mangyshlak, West Kazakhstan). In: Epicontinental Triassic (eds. Bachmann, G.H. \& Lerche, I.). E. Schweizerbart'sche Verlagsbuchandlung (Nägele u. Obermiller) Stuttgart. Zentralblatt für Geologie und Paläontologie, 3, 11-12, 1441-1462.

Balini, M., Lucas, S.G., Jenks, J.F. \& Spielmann, J.A. 2010. Triassic ammonoid biostratigraphy: an overview. In: The Triassic Timescale (ed. Lucas, S.G.). Geological Society, London, Special Publications, 334, 221-262.

Baud, A., Richoz, S., Beauchamp, B., Cordey, F., Grasby, S., Henderson, C.M., Krystyn, L. \& Nicora, A. 2011. The Buday'ah Formation, Sultanate of Oman: A Middle Permian to Early Triassic Oceanic Record of the Neotethys and the late Induan microsphere bloom. Journal of Asian Earth Sciences, 43, 130-144.

Belvedere, M., Avanzini, M., Mietto, P. \& Rigo, M. 2008. Norian dinosaur footprints from the "Strada delle Gallerie" (Monte Pasubio, NE Italy). Studi Trentini Di Scienze Naturali. Acta Geologica, 83, 267-275.

Bender, H. \& Stoppel, D. 1965. Perm-conodonten. Geologisches Jahrburg, 82, 331-364.

Benjamini, C., Hirsch, F. \& Eshet, Y. 2005. The Triassic of Israel. In: Geological Framework of the Levant Volume II: The Levantine Basin and Israel (eds. Hall, J.K., Krasheninnikov, V.A., Hirsch, F. Benjamini, C., \& Flexer, A.). Historical Productions Hall, 331-360.

Benton, M.J. \& Twitchett, R.J. 2003. How to kill (almost) all life: the end-Permian extinction event. Trends in Ecology and Evolution, 18, 358-364.

Beyers, J.M. \& Orchard, M.J. 1991. Upper Permian and Triassic conodont faunas from the type area of the Cache Creek Complex, south-central British Columbia, Canada. Geological Survey of Canada Bulletin, 417, 269-287.

Brack, P. \& Nicora, A. 1998. Conodonts from the Anisian - Ladinian succesion of Bagolino, Brescian Prealps (Brescia, Lombardy, Northern Italy). Stop 5.1. Giornale di Geologia, 6, 314-325.

Brack, P., Rieber, H., Nicora, A. \& Mundil, R. 2005. The Global boundary Stratotype Section and Point of the Ladinian Stage (Middle Triassic) at Bagolino (Southern Alps, Northern Italy) and its implications for the Triassic time scale. Episodes, 28, 233-244.

Branson, E.B., \& Mehl, M.G. 1946. Discussion. American Association of Petroleum Geologists Bulletin, 30, 616.

Budurov, K. \& Stefanov, S. A. 1973. Etliche neue PlattformConodonten aus der mitteltrias bulgariens. Comptes Rendus de l'Académie Bulgare des Sciences, 26, 803-806.
Budurov, K.J. \& Sudar, M.N. 1988. New Conodont Taxa from the Middle Triassic. Geology of Himalayas: Palaeontology, stratigraphy and structure; Contributions to Himalayan Geology, 4, 250-254.

Budurov, K.J. \& Sudar, M.N. 1990. Late Triassic Conodont Stratigraphy. Courier Forschungsinstitut Senckenberg, 118, 203-239.

Buryi, G.I. 1996. Evolution of the Late Triassic conodont platform elements. Acta Micropalaeontologica Sinica, 13, 135-142.

Buser, S., Kolar-Jurkovsek, T. \& Jurkovsek, B. 2007. Triasni konodonti Slovenskega bazena. Geologija, 50, 19-28.

Carter, E.S. \& Orchard, M.J. 2007. Radiolarian - conodont - ammonoid intercalibration around the Norian-Rhaetian Boundary and implications for trans-Panthalassan correlation. Albertiana, 36, 149-163.

Channell, J.E.T., Kozur, H.W., Sievers, T., Mock, R., Aubrecht, R. \& Sykora, M. 2003. Carnian-Norian biomagnetostratigraphy at Silická Brezová (Slovakia): correlation to other Tethyan sections and to the Newark Basin. Palaeogeography, Palaeoclimatology, Palaeoecology, 191, 65-109.

Chen, L. \& Wang, C. 2002. Triassic conodonts from Zhuganpo and "Wayao" formations of Guanling, Southwest China. Acta Palaeontologica Sinica, 41, 349-360.

Clark, D.L. 1983. Extinction of conodonts. Journal of Paleontology, 57, 652-661.

Clark, D.L. 1987. Conodonts: the final fifty million years. In: Paleobiology of Conodonts (ed. Aldridge, R.J.). British Micropaleontogical Society series, Ellis Horwood, Chichester, Sussex, 165-174.

De Renzi, M., Budurov, K. \& Sudar, M. 1996. The extinction of conodonts -in terms of discrete elements- at the Triassic-Jurassic boundary. Cuadernos de Geología Ibérica, 20, 347-364.

Eicher, D.B. 1946. Conodonts from the Triassic of Sinai (Egypt). American Association of Petroleum Geologists Bulletin, 30, 613-616.

Erwin, D. H. 2006. Extinction. How Life on Earth Nearly Ended 250 Million Years Ago. Princeton University Press. Princeton, New Jersey.

Fröbisch, N., Fröbisch, F., Martin Sander, P., Schmitz, L. \& Rieppel, O. 2012. Macropredatory ichthyosaur from the Middle Triassic and the origin of modern trophic networks. Proceedings of the National Academy of Sciences, 110, 1393-1407.

Goudemand, N., Orchard, M.J., Bucher, H. \& Jenks, J. 2012. The Elusive Origin of Chiosella timorensis (Conodonts, Triassic). Geobios, 45, 199-207.

Gullo, M. \& Kozur, H. 1989. Pseudofurnishius sosioensis n. sp. A new conodont species from the late Ladinian of Sosio valley, western Sicily (Italy). Geologisch Paläontologische Mitteilungen Innsbruck, 16, 207-211.

Gullo, M. \& Kozur, H. 1992. Conodonts from the pelagic deep-water Permian of central western Sicily (Italy). Neues Jahrbuch für Geologie und Paläeontologie. Abhandlungen, 184, 203-234. 
Hallam, A. \& Wignal, P.B. 1997. Mass Extintion and their Aftermath. Oxford University Press.

Hayashi, S. 1968. The Permian conodonts in Chert of the Aoyama Formation, Ashio Mountains, Central Japan. Chikyu Kagaku (Earth Science), 22, 63-77.

Hirsch, F. 1994. Triassic conodonts as ecological and eustatic sensors. Pangea: Global Environments and Resources Canadian Society of Petroleum Geologists, Memoir 17, 949-959.

Henderson, C.M. 1997. Uppermost Permian conodonts and the Permian - Triassic boundary in the western Canada Sedimentary Basin. Bulletin of Canadian Petroleum Geology, 45, 693-707.

Hornung, T., Spatzenegger, A. \& Joachimski, M.M. 2007. Multistratigraphy of condensed ammonoid beds of the Rappoltstein (Berchtesgaden, southern Germany): unravelling palaeoenvironmental conditions on 'Hallstatt deep swells' during the Reingraben Event (Late Lower Carnian). Facies, 53, 267-292.

Ishida, K. \& Hirsch, F. 2001. Taxonomy and faunal affinity of Late Carnian - Rhaetian conodonts in the Southern Chichibu Belt, Shikoku, SW Japan. Rivista Italiana di Paleontologia e Stratigrafia, 107, 227-250.

Ishida, K., Nanba, A., Hirsch, F., Kozai, T. \& Meesook, A. 2006. New micropalaentological evidence for a Late Triassic Shan-Thai orogeny. Geosciences Journal, 10, 181-194.

Ji, W., Tong, J., Zhao, L., Zhou, S. \& Chen, J. 2010. Lower-Middle Triassic conodont biostratigraphy of the Qingyan section, Guizhou Province, Southwest China. Palaeogeography, Palaeoclimatology, Palaeoecology, 308, 213-223.

Jiang, H., Lai, X., Luo, G., Aldridge, R., Zhang, K. \& Wignall, P. 2007. Restudy of conodont zonation and evolution across the $\mathrm{P} / \mathrm{T}$ boundary at Meishan section, Changxing, Zhejiang, China. Global and Planetary Change, 55, 39-55.

Jiang, H., Aldridge, R.J., Lai, X., Yan, C. \& Sun, Y. 2011a. Phylogeny of the conodont genera Hindeodus and Isarcicella across the Permian-Triassic boundary. Lethaia, 44, 374-382.

Jiang, H., Lai, X., Yan, C., Aldridge, R.J., Wignall, P. \& Sun, Y. 2011b. Revised conodont zonation and conodont evolution across the Permian-Triassic boundary at the Shangsi section, Guangyuan, Sichuan, South China. Global and Planetary Change, 77, 103-115.

Koike, T. 1998. Triassic coniform conodont genera Aduncodina and Neostrachanognathus. Paleontological Research, 2, 120-129.

Koike, T. 1999. Apparatus of a Triassic conodont species Cratognathodus multihamatus (Huckriede). Paleontological Research, 3, 234-248.

Koike, T., Kobayashi, E. \& Ozawa, T. 1985. Smithian (Lower Triassic) conodonts from Iwai, Hinode-Machi, NishitamaGum, Tokio-To, Japan. Science Reports of the Yokohama National University. Section 2: Biological and Geological Sciences, 32, 45-56.
Koike, T., Yamakita, S. \& Kadota, N. 2004. A natural assemblage of Ellisonia sp. cf. E. triassica Müller (Vertebrata: Conodonta) from the uppermost Permian in the Suzuka Mountains, central Japan. Paleontological Research, 8, 241-253.

Kolar-Jurkovsek, T. 1982. Konodonti iz amfliklinskih skladov in baskega dolomita Conodonts from Amphiclina beds and Baca Dolomite. Geologija, 25, 167-188.

Kolar-Jurkovsek, T. 2011. Latest Triassic conodonts of the Slovenian Basin and some remarks on their evolution. Geologija, 54, 81-90.

Korte, C. \& Kozur, H.W. 2010. Carbon-isotope stratigraphy across the Permian-Triassic boundary: A review. Journal of Asian Earth Sciences, 39, 215-235.

Kovács, S. 1994. Conodonts of stratigraphical importance from the Anisian / Ladinian boundary interval of the Balaton Highland, Hungary. Rivista Italiana di Paleontologia e Stratigrafia, 99, 473-514.

Kovács, S. \& Kozur, H. 1980. Stratigraphische Reichweite der wichtingsten Conodonten (ohre Zahnriehenconodonten) der Mittel-und Obertrias. Geologisch - Paläontologische Mitteilungen Innsbruck, 10, 47-78.

Kozur, H.W. 1975. Beitrage zur conodontenfauna des Perm. Geologisch - Paläontologische Mitteilungen Innsbruck, 5, 1-41.

Kozur, H. 1989. The taxonomy of the gondolellid conodonts in the Permian and Triassic. Courier Forschungsinstitut Senckenberg, 117, 409-469.

Kozur, H 1990. Significance of Events in Conodont Evolution for the Permian and Triassic Stratigraphy. Courier Forschungsinstitut Senckenberg, 117, 385-408.

Kozur, H. 1993. First evidence of Liassic in the vicinity of Csővár (Hungary), and its palaeogeographic and palaeotectonic significance. Jahrbuch der Geologischen Bundesanstalt, 136, 89-98.

Kozur, H. 1995a. Permian conodont zonation and its importance for the Permian stratigraphic standard scale. Geologisch - Paläontologische Mitteilungen Innsbruck, 20, 165-205.

Kozur, H. 1995b. Some remarks to the conodonts Hindeodus and Isarcicella in the latest Permian and earliest Triassic. Palaeoworld, 6, 64-77.

Kozur, H. 1996. The conodonts Hindeodus, Isarcicella and Sweetohindeodus in the Uppermost Permian and Lowermost Triassic. Geologia Croatica, 49, 81-115.

Kozur, H.W. 2003. Integrated ammonoid, conodont and radiolarian zonation of the Triassic and some remarks to Stage/Substage subdivision and the numeric age of the Triassic stages. Albertiana, 28, 57-74.

Kozur, H.W. 2004. Pelagic uppermost Permian and the Permian-Triassic boundary conodonts of Iran. Part I: Taxonomy. Hallesches Jahrbuch fur Geowissenschaften Reihe B., 18, 39-68.

Kozur, H.W. 2005. Pelagic uppermost Permian and the Permian-Triassic boundary conodonts of Iran. Part II: Investigated sections and evaluation of the conodont faunas. Geological Society of America, Abstracts with programs, 19, 49-86. 
Kozur, H. 2007. Biostratigraphy and event stratigraphy in Iran around the Permian-Triassic Boundary (PTB): Implications for the causes of the PTB biotic crisis. Global and Planetary Change, 55, 155-176.

Kozur, H. \& Mock, R. 1974. Zwei neue Conodonten-Arten aus der trias des slowakischen Karstes. Casopis pro Mineralogii a Geologii, 19, 135-139.

Kozur, H., Krainer, K. \& Mostler, H. 1994. Middle Triassic conodonts from the southern Karawanken Mountains (southern Alps) and their stratigraphic importance. Geologisch - Paläontologische Mitteilungen Innsbruck, 19, 165-200.

Kozur, H., Krainer, H. \& Mostler, H. 1997. Neospathodus sosioensis n. sp., a new conodont species from the late Olenekian (uppermost Scythian) of western Sicily, Italy. News of Osaka Micropaleontologists, Special Volume. In: Proceedings of the Fifth Radioalarian Symposium (ed. Yao, A.), 10, 109-113.

Kozur, H. \& Mock, R. 1991. New Middle Carnian and Rhaetian conodonts from Hungary and the Alps. Stratigraphic importance and tentative implications for the Buda Mountains and adjacent areas. Jahrbuch der Geologischen Bundesanstalt, 134, 271-297.

Kozur, H.W. \& Weems, R.E. 2011. Detailed correlation and age of continental late Changhsingian and earliest Triassic beds: Implications for the role of the Siberian Trap in the Permian-Triassic biotic crisis. Palaeogeography, Palaeoclimatology, Palaeoecology, 308, 22-40.

Krystyn, V. L. 1983. Das Epidaurus-Profil (Griechenland) - ein Beitrag zur conodonteb-standardzonierung des tethyalen Ladin und Unterkarn. Neue Beiträge zur Biostratigraphie der Tethys-Trias, 5, 231-258.

Krystyn, L. 2008. An ammonoid-calibrated tethyan conodont time scale of the Late Upper Triassic. Berichte der Geologischen Bundesanstalt, 76, 9-11.

Krystyn, L., Mandl, G.W. \& Schauer, M. 2009. Growth and termination of the Upper Triassic platform margin of the Dachstein area (Northern Calcareous Alps, Austria). Austrian Journal of Earth Sciences, 102, 23-33.

Krystyn, L., Richoz, S., Gallet, Y., H. Bouquerel, H., Kürschner, W.M. \& Spötl, C. 2007. Updated bio- and magnetostratigraphy from Steinbergkogel (Austria), candidate GSSP for the base of the Rhaetian stage. Albertiana, 36, 164-173.

Lehrmann, D.J., Ramezani, J., Bowring, S.A., Martin, M.W., Montgomery, P., Enos, P., Payne, J.L., Orchard, M.J., Wang, H. \& Wei, J. 2006. Timing of recovery from the end-Permian extinction: Geochronologic and biostratigraphic constraints from south China. Geology, 34, 1053-1056.

Liang, D., Tong, J. \& Zhao, L. 2011. Lower Triassic SmithianSpathian Boundary at West Pingdingshan Section in Chaohu, Anhui Province. Science China Earth Sciences, 54, 372-379.

March, M., Budurov, K., Hirsch, F. \& Márquez-Aliaga, A. 1990. Sephardiella nov. gen. (Conodonta), Emendation of Carinella (Budurov, 1973 from the Ladinian (Middle
Triassic) type area in Catalonia (N. E. Spain). Sephardic Province. Courier Forschungsinstitut Senckenberg, 118, 197-201.

Márquez-Aliaga, A., Valenzuela-Ríos, J.I, Calvet, F. \& Budurov, K. 2000. Middle Triassic conodonts from northeastern Spain: biostratigraphic implications. Terra Nova, 12, 77-83.

Mastandrea, A., Neri, C. \& Russo, F. 1997. Conodont biostratigraphy of the S. Cassiano Formation surrounding the Sella Massif (Dolomites, Italy): implications for sequence stratigraphic models of the Triassic of the Southern Alps. Rivista Italiana di Paleontologia $e$ Stratigrafia, 103, 39-52.

Mazza, M., Furin, S., Spötl, C. \& Rigo, M. 2010. Generic turnovers of Carnian/Norian conodonts: Climatic control or competition?. Palaeogeography, Palaeoclimatology, Palaeoecology, 290, 120-137.

Mazza, M., Rigo, M. \& Nicora, A. 2011. A new Metapolygnathus platform conodont species and its implications for Upper Carnian global correlations. Acta Palaeontologica Polonica, 56, 121-131.

Mazza, M., Rigo, M. \& Gullo, M. 2012. Taxonomy and biostratigraphic record of the upper Triassic conodonts of the Pizzo Mondello section (Western Sicily, Italy), GSSP candidate for the base of the Norian. Rivista Italiana di Paleontologia e Stratigrafia, 118, 85-130.

Meço, S. 1999. Conodont Biostratigraphy of Triassic pelagic Strata, Albania. Rivista Italiana di Paleontologia e Stratigrafia, 105, 251-266.

Mei, S., Jin, Y. \& Wardlaw, B.R. 1994. Succession of Wuchiapingian conodonts from northeastern Sichuan and its worldwide correlation. Acta Micropaleontologica Sinica, 11, 121-139.

Mei, S., Zhang, K. \& Wardlaw, B.R. 1998. A refined zonation of Changhsingian and Griesbachian gondolellid conodonts from the Meishan Section, candidate of the global stratotype section and point of the Permian Triassic Boundary. Palaeogeography, Palaeoclimatology, Palaeoecology, 143, 213-226.

Mei, S., Henderson, C.M. \& Wardlaw, B.R. 2002. Evolution and distribution of the conodonts Sweetognathus and Iranognathus and related genera during the Permian, and their implications for climate change. Palaeogeography, Palaeoclimatology, Palaeoecology, 180, 57-91.

Mei, S., Henderson, C.M. \& Cao, C. 2004. Conodont sample-population approach to defining the base of the Changhsingian Stage, Lopingian Series, Upper Permian. In: The Palynology and Micropalaeontology of Boundaries (eds. Beaudoin, A.B. \& Head, M.J.). Geological Society, London, Special Publications, 230, 105-121.

Mietto, P. \& Petroni, M. 1980. The Ladinian platform conodonts in the Camogrosso section (Recoaro Area, northeast Italy) and their stratigraphic significance. Rivista Italiana di Paleontologia e Stratigrafia, 86, 534-562.

Mietto, P., Buratti, N., Cirilli, S., De Zanche, V., Gianolla, P., Manfrin, S., Nicora, A., Preto, N., Rigo, M. \& Roghi, G. 2007. New constraints for the Ladinian-Carnian Boundary 
in the southern Alps: suggestions for global correlations. In: The Global Triassic (eds. Lucas, S.G. \& Spelmann, J.A.). New Mexico Museum of Natural History and Science Bulletin, 41, 275-281.

Metcalfe, I., Nicoll, R.S. \& Willink, R.J. 2008. Conodonts from the Permian-Triassic transition in Australia and position of the Permian-Triassic boundary. Australian Journal of Earth Science, 55, 365-377.

Moix, P., Kozur, H.W., Stampfli, G.M. \& Mostler, H. 2007. New paleontological, biostratigraphic and paleogeographic results from the Triassic of the Mersin Mélange, SE Turkey. In: The Global Triassic (eds. Lucas, S.G. \& Spelmann, J.A.). New Mexico Museum of Natural History and Science Bulletin, 41, 282-311.

Mosher, L.C. 1968. Triassic conodonts from Western North America and Europe and their correlation. Journal of Paleontology, 42, 895-946.

Mosher, L.C. 1973. Triassic conodonts from British Columbia and the Northern Artic Islands. Geological Survey of Canada Bulletin, 222, 141-148.

Müller, K.J. 1956. Triassic conodonts from Nevada. Journal of Paleontology, 30, 818-830.

Müller, K.J. 1962. Zur systematischen Einteilung der Conodontophorida. Paläontologische Zeitschrift, 30, 818-830.

Muttoni, G., Gaetani, M., Budurov, K., Zargorchev, I., Trifonova, Ivanova, D., Petrounova, L. \& Lowrie, W. 2000. Middle Triassic paleomagnetic data from northern Bulgaria: constraints on Tethyan magnetostratigraphy and paleogeography. Palaeogeography, Palaeoclimatology, Palaeoecology, 160, 223-237.

Muttoni, G., Kent, D.V., Jadoul, F., Olsen, P.E., Rigo, M., Galli, M.T. \& Nicora, A. 2010. Rhaetian magneto-biostratigraphy from the Southern Alps (Italy): Constraints on Triassic chronology. Palaeogeography, Palaeoclimatology, Palaeoecology, 285, 1-16.

Muttoni, G., Nicora, A., Brack, P. \& Kent, D.V. 2004. Integrated Anisian-Ladinian boundary chronology. Palaeogeography, Palaeoclimatology, Palaeoecology, 208, 85-102.

Nafi, M. Xia, W. \& Zhang, N. 2006. Late Permian (Changhsingian) conodont biozonation and the basal boundary, Ganxi section, western Hubei Province, south China. Canadian Journal of Earth Sciences, 43, 121-133.

Nakazawa, K., Ishibashi, T., Kimura, T., Koike, T., Shimizu, D. \& Yao, A. 1994. Triassic biostratigraphy of Japan based on various taxa. Mémoires de Géologie, 22, 83-102.

Nakrem, H.A., Orchard, M.J., Weitschat, W., Hounslow, M.W. Beatty, TW. \& Mørk, A. 2008. Triassic conodonts from Svalbard and their Boreal correlations. Polar Research, 27, 523-539.

Narkiewicz, K. 1999. Conodont biostratigraphy of the Muschelkalk (Middle Triassic) in the central part of the Polish Lowlands. Geological Quarterly, 42, 313-328.

Narkiewicz, K. \& Szulc, J. 2004. Controls on migration of conodont fauna in peripheral oceanic areas. An example from the Middle Triassic of the Northern Peri-Tethys. Geobios, 37, 425-436.
Noyan, O.F. \& Kozur, H.W. 2007. Revision of the late Carnian - early Norian conodonts from the Stefanion section (Argolis, Greece) and their palaeobiogeographic implications. Neues Jahrbuch für Geologie und Paläeontologie. Abhandlungen, 245, 159-178.

Nicora A., Balini M., Bellanca, A., Bertinelli, A., Bowring, S.A., Di Stefano, P., Dumitrica, P., Guaiumi C., Gullo M., Hungerbuehler, A., Levera, M., Mazza, M., McRoberts, C., Muttoni G., Preto N. \& Rigo, M. 2007. The Carnian/ Norian boundary interval at Pizzo Mondello (Sicani Mountains, Sicily) and its bearing for the definition of the GSSP of the Norian Stage. Albertiana, 36, 102-129.

Ogg, J.G \& Ogg, G. 2006a. Permian / Triassic (236-273 Ma time-slice). https://engineering.purdue.edu/ Stratigraphy/charts/Timeslices/8_Lower_Triassic.pdf

Ogg, J.G \& Ogg, G. 2006b. Late Triassic (199-235 Ma timeslice). https://engineering.purdue.edu/Stratigraphy/ charts/Timeslices/7_Upper_Trias.pdf.

Orchard, M.J. 1991. Upper Triassic conodont biochronology and new index species from the Canadian Cordillera. Geological Survey of Canada Bulletin, 417, 299-335.

Orchard, M.J. 1995. Taxonomy and correlation of Lower Triassic (Spathian) segminate conodonts from Oman and revision of some species of Neospathodus. Journal of Paleontology, 69, 110-122.

Orchard, M.J. 2007a. Conodont diversity and evolution through the latest Permian and Early Triassic upheavals. Palaeogeography, Palaeoclimatology, Palaeoecology, 252, 93-117.

Orchard, M.J. 2007b. New conodonts and zonation, LadinianCarnian Boundary beds, British Columbia, Canada. In: The Global Triassic (eds. Lucas, S.G. \& Spelmann, J.A.). New Mexico Museum of Natural History and Science Bulletin, 41, 321-330.

Orchard, M.J. 2008. Lower Triassic conodonts from the Canadian Artic, their intercalibration with ammonoidbased stages and a comparison with other North American Olenekian faunas. Polar Research, 27, 393-412.

Orchard, M.J. 2010. Triassic conodonts and their role in stage boundary definition. In: The Triassic Timescale (ed. Lucas, S.G.). Geological Society, London, Special Publications, 334, 139-161.

Orchard, M.J., Krystyn, L. 1998. Conodonts of the lowermost Triassic of Spiti, and new zonation based on Neogondolella succesions. Rivista Italiana di Paleontologia e Stratigrafia, 104, 341-368.

Orchard, M.J., Cordey, F., Rui, L., Bamber, E.W., Mamet, B., Struik, L.C., Sano, H. \& Taylor, H.J. 2001a. Biostratigraphic and biogeographic constraints on the Carboniferous to Jurassic Cache Creek in central British Columbia. Canadian Journal of Earth Sciences, 38, 551-578.

Orchard, M.J., Lehrmann, Jiayong, W., Hongmei, W. \& Taylor, H.J. 2007a. Conodonts from the Olenekian-Anisian Boundary Beds, Guandao, Guizhou Province, China. In: The Global Triassic (eds. Lucas, S.G. \& Spelmann, J.A.). New Mexico Museum of Natural History and Science Bulletin, 41, 347-354. 
Orchard, M.J. \& Tozer, E.T. 1997. Triassic conodont biochronology, its calibration with the ammonoid standard, and a biostratigraphic summary for the Western Canada Sedimentary basin. Canadian Society of Petroleum Geologists Bulletin, 45, 675-692.

Orchard, M.J., Whalen, P.A., Carter, E.S. \& Taylor, H.J. 2007b. Latest Triassic conodonts and radiolarian-bearing successions in Baja California Sur. In: The Global Triassic (eds. Lucas, S.G. \& Spelmann, J.A.). New Mexico Museum of Natural History and Science Bulletin, 41, 355-365.

Orchard, M.J. \& Zonneveld, J-P. 2009. The Lower Triassic Sulphur Mountain Formation in the Wapiti Lake area: lithostratigraphy, conodont biostratigraphy and a new conodont biozonation for the lower Olenekian (Smithian). Canadian Journal of Earth Sciences, 46, 757-790.

Orchard, M.J., Zonneveld, J.P., Johns, M.J., McRoberts, C.A., Sandy, M.R., Tozer, E.T. \& Carrelli, G.G. 2001b. Fossil succesion and sequence stratigraphy of the Upper Triassic of Black bear Ridge, a GSSP prospect for the CarnianNorian boundary. Albertiana, 25, 10-22.

Pálfy, J., Demény, A., Haas, J., Carter, E.S., Görög, A., Halász. D., Oravecz-Scheffer, A., Hetényi, M., Márton, E., Orchard, M.J., Péter Ozsvárt, P., Vető, I. \& Zajzon, N. 2007. Triassic-Jurassic boundary events inferred from integrated stratigraphy of the Csővár section, Hungary. Palaeogeography, Palaeoclimatology, Palaeoecology, 244, 11-33.

Perri, M.C. 1991. Conodont biostratigraphy of the Werfen Formation (Lower Triassic), southern Alps, Italy. Bollettino della Società Paleontologica Italiana, 30, 23-46.

Perri, M.C. \& Andraghetti, M. 1987. Permian-Triassic boundary and Early Triassic conodonts from the southern Alps. Italy. Rivista Italiana di Paleontologia e Stratigrafia, 93, 291-328.

Perri, M.C. \& Farabegoli, E. 2003. Conodonts across the Permian-Triassic boundary in the Southern Alps. Courier Forschungsinstitut Senckenberg, 245, 281-313.

Plasencia, P. 2009. Bioestratigrafía y paleobiología de conodontos del Triásico Medio del Sector Oriental de la Península Ibérica. Servei de Publicacions de la Universitat de Valencia.

Plasencia, P., Hirsch, F. \& Márquez-Aliaga, A. 2007. Sephardiellinae, a new Middle Triassic conodont subfamily. Journal of Iberian Geology, 33, 163-172.

Plasencia, P. \& Márquez-Aliaga, A. 2005. Aportaciones al estudio de la recuperación y extinción de los conodontos durante el Triásico. Geotemas, 8, 229-232.

Plasencia, P. \& Márquez-Aliaga, A. 2011. Discussion about the stratigraphic range of Pseudofurnishius murcianus van den Boogaard (Conodonta) in the Iberian Peninsula, from the Calasparra section (Murcia, Spain). Journal of Iberian Geology, 37, 153-160.

Posenato, R. 2008. Global correlations of mid Early Triassic events: The Induan/Olenekian boundary in the Dolomites (Italy). Earth-Science Reviews, 91, 93-105.

Rexroad, C.B., Furnish, W.M. 1964. Conodonts from the Pella Formation (Mississipian) of south-central Iowa. Journal of Paleontology, 38, 557-576.
Rigo, M., Preto, N. Roghi, G. Tateo, F. \& Mietto, P. 2007. A rise in the Carbonate Compensation Depth of western Tethys in the Carnian (Late Triassic): Deep-water evidence for the Carnian Pluvial Event. Palaeogeography, Palaeoclimatology, Palaeoecology, 246, 188-205.

Rozic, B., Kolar-Jurkovsek, T. \& Smuc A. 2009. Late Triassic sedimentary evolution of Slovenian Basin (eastern Southern Alps): description and correlation of the Slatnik Formation. Facies, 55, 137-155.

Sepkoski, J.J. 1981. A Factor Analytic Description of the Phanerozoic Marine Fossil Record. Paleobiology, 7, 36-53.

Sepkoski, J.J. 1996. Patterns of Phanerozoic extinction: a perspective from global data bases. In: Global events and event stratigraphy in the Phanerozoic (ed. Walliser, O.H.). Springer, Berlin, 35-51.

Shen, S.Z. 2007. The conodont species Clarkina orientalis (Barskov and Koroleva, 1970) and its spatial and temporal distribution. Permophiles, 50, 25-37.

Shen, S. \& Mei, S. 2010. Lopingian (Late Permian) high-resolution conodont biostratigraphy in Iran with comparison to South China zonation. Geological Journal, 45, 135-161.

Stanley, S.M. 2009. Evidence from ammonoids and conodonts for multiple Early Triassic mass extinctions. Proceedings of the National Academy of Sciences, 106 , 15264-15267.

Sun, Z, Sun, Y., Hao, W. \& Jiang, D. 2006. Conodont Evidence for the Age of the Panxian Fauna, Guizhou, China. Acta Geologica Sinica, 80, 621-630.

Sweet, W.C. \& Mei, S. 1999. The Permian Lopingian and Basal Triassic Sequence in Northwest Iran. Permophiles, 33, 1-18.

Swift, A. 1989. First records of conodonts from the Late Triassic of Britain. Palaeontology, 32, 325-333.

Tatge, U. 1956. Conodonten aus dem Germanischen Muschelkalk. I. Teil. Paläontologische Zeitschrift, 30, 108-127.

Trammer, J. 1975. Stratigraphy and facies development of the Muschelkalk in the south-western Holy Cross Mountains. Acta Geologica Polonica, 25, 179-216.

Vrielynck, B. 1984. Révision des gisements à conodontes de l'Anisien Supérieur et du Ladinien des Alpes Carniques occidentales et de dolomites (Italie du Nord). Geobios, 17, 177-199.

Wang, C.-Y., Ritter, S.M. \& Clark, D.L. 1987. The Sweetognathus complex in the Permian of China: implications for evolution and homeomorphy. Journal of Paleontology, 61, 1047-1057.

Yang, S. 1995. Ladinian - Carnian condonts and their biostratigraphy in Asia. Journal of Geology, Series B, 5-6, 127-138.

Youngquist, W.L. 1952. Triassic conodonts from southeastern Idaho. Journal of Paleontology, 26, 650-655.

Zhao, L. 2004. Study on the Lower Triassic Conodont Sequence and Discussion on the Induan-Olenekian Boundary in Chaohu, Anhui Province. China University of Geosciences. 
Zhao L., Orchard, M.J., Tong J., Sun Z., Zuo J., Zhang S. \& Yun A. 2007. Lower Triassic conodont sequence in Chaohu, Anhui Province, China and its global correlation. Palaeogeography, Palaeoclimatology, Palaeoecology, 252, 24-38.
Zhao L., Tong J. \& Zhang, S. 2008. An Update of Conodonts in the Induan-Olenekian Boundary Strata at West Pingdingshan Section, Chaohu, Anhui Province. Journal of China University of Geosciences, 19, 207-216. 